ERIC VACCARella, Estrangeros, uellacos, santos y rreys: la representación de los negros en la obra de Felipe Guamán Poma de Ayala ... ...........

Ramón García Castro, Epistemología del closet de José Donoso (19241996) en Conjeturas sobre la memoria de mi tribu (1996), El jardín de al lado (1981) y “Santelices” (1962) ... ..............................

IgnACIO García, Rubén Darío y Francisco Grandmontagne en el Buenos Aires de 1898. La redefinición de los conceptos de hispanismo en América y de americanismo en España $\ldots \ldots \ldots \ldots \ldots \ldots \ldots \ldots \ldots \ldots \ldots \ldots$ Jorge Rosario-Vélez, Somos un sueño imposible: ¿clandestinidad sexual del bolero en La última noche que pasé contigo de Mayra Montero? .......

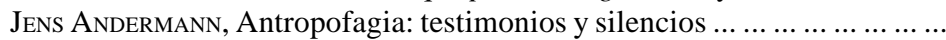
Kristine IBSEn, Cadáveres exquisitos: colecciones y colonialismo en Noticias

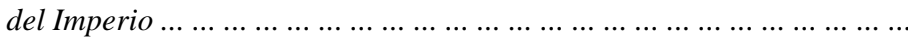

Claudia A. Roman, Paulino Lucero: táctica y sintaxis ... ... .............. María Dolores Jaramillo, Abdón Ubidia: rostros y rastros de la ciudad ... Graciela Batticuore, Sarmiento: lector de imágenes, escritor de prodigios Edmundo Paz Soldán, Vanguardia e imaginario cinemático: Vicente

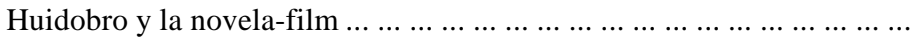

JAson Cortés, Buscando al otro: ética y alteridad en "Página en blanco y

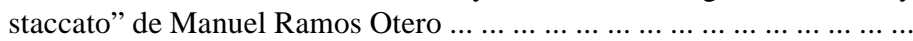

\title{
II. ENTREVISTAS
}

NÉstor E. Rodríguez, Un arte de hacer ruinas: entrevista con el escritor

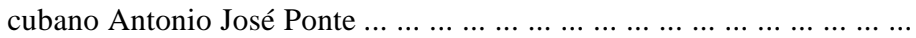

Pablo A. J. Brescia, De aflicciones, travesías y deseos: conversación con

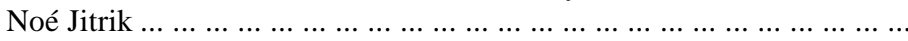


III. NeCROLÓGICA

Ignacio M. SÁnchez-Prado, Juan José Arreola (1918-2001): La magia ha

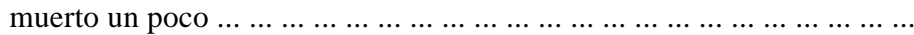

IV. RESEÑAS

Miguel Gomes sobre Vivian Schelling, Through the Kaleidoscope: The Experience of Modernity in Latin America ... ... ... .................... . NÉstor Rodríguez sobre John Dimitri Perivolaris, Puerto Rican Cultural Identity and the Work of Luis Rafael Sánchez ... ..................... Claudia Caisso sobre Anthony Stanton, Correspondencia Alfonso Reyes /

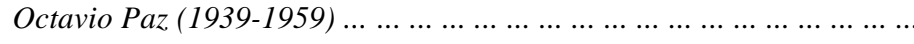
Claudia Caisso sobre Anthony Stanton, Inventores de tradición: ensayos sobre poesía mexicana moderna $\ldots \ldots \ldots \ldots \ldots \ldots \ldots \ldots \ldots \ldots \ldots \ldots \ldots$ 